\title{
ラット動脈に上る prostacyclin $\left(\mathrm{PGI}_{2}\right)$ の産生に䦙する 研究，とくに高血圧ラット (SHR) における 産生の立進についで 大熊稔* 家森幸男** 内野治 人*
}

\author{
Studies on Prostacyclin $\left(\mathrm{PGI}_{2}\right)$ Production by Rat Aorta \\ with Special Reference to the Enhanced Production \\ in Spontaneously Hypertensive Rats (SHR)
}

\author{
Minoru OKUMA*, Yukio YAMORI** and Haruto UCHINO*
}

Key words : stroke-prone SHR (SHRSP), stroke-resistant SHR (SHRSR), platelet aggregation, cyclooxygenase, prostacyclin synthetase

Prostacyclin $\left(\mathrm{PGI}_{2}\right)$ production by rat aortae under various conditions was investigated and activities of the aorta to produce this substance in stroke-prone spontaneously hypertensive rats (SHRSP), stroke-resistant SHR (SHRSR) and normotensive control rats from the Wistar-Kyoto (WK) colony were compared.

Except for some preliminary experiments to establish the test system, only age-matched male animals ( 6 months) before the development of stroke were utilized (5 animals in each group). The descending aorta was removed from each animal, washed and used immediately or stored at $-20^{\circ} \mathrm{C}$ until use. Fine rings of the aorta were routinely incubated in $0.25-1.0 \mathrm{ml}$ of $\mathrm{pH} 9.0$ boratebuffered saline for $1 \mathrm{hr}$ at $20^{\circ} \mathrm{C}$. Volumes $(1-10 \mu \mathrm{l})$ of the buffered saline in which the aortic rings had been incubated were added to $0.2 \mathrm{ml}$ human plateletrich plasma (PRP) 1 min before the addition of collagen. Platelet aggregation was monitored in a Sienco dual sample aggregometer. The amount of prostacyclin produced by the aorta was estimated by comparison of its anti-aggregatory activity with thay produced by known amounts of authentic prostacyclin- $\mathrm{Na}$.

Rings of the aorta incubated as described above produced increasing prostacyclin-like activity, as shown by the strong inhibition of ADP-, collagen- and arachidonate-induced platelet aggregation for up to $1 \mathrm{hr}$ (Fig. 1) and the activity was dependent on the volume of buffered-saline added as well as on the length of aortae incubated. The activity produced by incubation of the aorta in $\mathrm{pH} 7.4$ Tris-buffered saline for longer than $20 \mathrm{~min}$ at $20^{\circ} \mathrm{C}$ decreased progressively during the incubation and disappeared within $1 \mathrm{hr}$ (Fig. 1), confirming the lability of prostacyclin at $\mathrm{pH}$ 7.4. Incubation of the aorta boiled for $3 \mathrm{~min}$ produced

* 京都大学医学部内科第一講座〔T606 京都市左京区聖護院川原町54〕, The First Division, Department of Internal Medicine, Faculty of Medicine, Kyoto University, Kyoto, Japan.

** 島根医科大学病理, Department of Pathology, Shimane National Medical School, Izumo Japan. 
no such activity. The spontaneous generation by the aorta of prostacyclin was inhibited by preincubation of the aorta with indomethacin (cyclo-oxygenase inhibitor), while the generation induced by $\mathrm{PGH}_{2}$ was not (Fig. 2). These results indicate that the aorta has both cyclo-oxygenase and prostacyclin synthetase.

Amounts of prostacyclin generated by the aorta of SHRSP and SHRSR were significantly higher than those of WK rats (Fig. 3). Although the meaning of the enhanced production of prostacyclin by the aorta of these hypertensive rats is not clear at the moment, it could be a physiological defence mechanism against the development of vascular injuries possibly due to hypertension in these animals and stroke might be triggered by the development of any inhibitory mechanisms against prostacyclin synthesis by the vessel of SHRSP.

\section{はじめに}

最近 Vane らによりウシやブタ動脈の microsome が prostaglandin (PG) $\mathrm{H}_{2}$ から PGX (prostacyclin, $\mathrm{PGI}_{2}$ ) と称される不安定な物質 を生成し，乙の物質は強い血小板凝集抑制作用 や摘出血管の弛緩作用などを有することが明ら かにされた1). その後ヒトやラットの血管によ っても $\mathrm{PGI}_{2}$ と考元られる物質の産生されるこ とが報告されており ${ }^{2) 3}$ ， $\mathrm{PGI}_{2}$ は天然の抗血栓 性物質ではないかと推察されるに至っている.

われわれは，まずラット動脈による $\mathrm{PGI}_{2}$ 産生 の定量的な検討を行うべく基礎的な実験を行 い, さらに高血圧自然発症ラット (SHR) の大 動脈による $\mathrm{PGI}_{2}$ 産生を正常血圧ラットのそれ と比較検討しているので得られた知見を報告す る。

\section{I. 実験材料および実験方法}

基礎的実験には主として生後 6 〜 10ケ月のラ ットを用いた．高血圧ラットと正常ラットの $\mathrm{PGI}_{2}$ 産生を比較した実験では，すべて生後 6 ケ月で雄性のむのを用いた。すなわち，まだ脳 卒中発作のみられない脳卒中易発症高血圧ラッ 卜 $(\mathrm{SHRSP})^{4)}$, 脳卒中難発症 高血圧 ラット $(\mathrm{SHRSR})^{4)}$ おょび正常血圧の Wistar-Kyoto (WK) 系ラット4) で各 5 匹ずつを使用した。 pentobarbitone sodium の腹腔内注射でラット を麻酔した後, 下降大動脈を分離摘出し, 冷生 食水で洗滌後速やかに使用するかー $-20^{\circ} \mathrm{C}$ 亿保存 し1ケ月以内に使用した. 使用時凍結した大動 脈は室温で融解させ, 直ちに輪状に切断 (通常
長さ $1 \sim 2 \mathrm{~mm}$ ) し, $0{ }^{\circ} \mathrm{C}$ で保存しながら 1 時 間以内に用に供した。

$\mathrm{PGI}_{2}$ 産生は上記の大動脈片を $0.25 \sim 1.0 \mathrm{~m} l$ の buffered saline 中に $20^{\circ} \mathrm{C}$ で incubate した後, 上清の aliquot $(1 \sim 10 \mu l)$ を多血小板血漿 (PRP) に加え, 1 分間 $37^{\circ} \mathrm{C}$ で incubate してか ら凝集剂をこれに加えた際にみられる血小板凝 集抑制効果で検討した.PRP の作成および血 小板凝集は既報5) に準じて行った. 血小板凝集 剂としては通常 collagen (Hormon-Chemie) を 用い，その濃度は各 PRP について最大の透光 度の変化を惹起させるに必要な最少量（終濃度 $0.6 \sim 2 \mu \mathrm{g} / \mathrm{m} l)$ とした. $\mathrm{PGI}_{2}$ の定量は種々な量 の $\mathrm{PGI}_{2}-\mathrm{Na}$ 塩を $\mathrm{PRP}$ に加えた際の collagen 凝集阻害率より作成した標準曲線を用いて行っ た. buffered saline は各種の buffer $(\mathrm{pH} 6.7$ : phosphate; $\mathrm{pH} 7.4$ 打よび $\mathrm{pH} 8.0$ : Tris- $\mathrm{HCl}$; $\mathrm{pH} 9.0$ および $\mathrm{pH} 10.1$ : borate) 亿生食水を 加えて作成し， ADP 扔よび arachidonic acid (AA) は Sigma 製品を, $\mathrm{PGI}_{2}-\mathrm{Na}$ および $\mathrm{PG}$ $\mathrm{H}_{2}$ は小野薬品中央研究所より提供されたもの をそれぞれ用いた。

\section{II. 実験成績および考察}

\section{1. $\quad \mathbf{P G I}_{2}$ の安定性}

$\mathrm{PGI}_{2}$ は $\mathrm{pH} 7.4$ 附近の水溶液中では不安 定 $^{136)}$ で, $\mathrm{pH}>8.5$ では比較的安定 ${ }^{6)}$ なとよが 報ぜられているが詳細な点が不明なため，まず $\mathrm{PGI}_{2}$ の安定性を検討した. すなわち $\mathrm{PGI}_{2}-\mathrm{Na}$ 塩のエタノール溶液を種々な $\mathrm{pH}$ の buffered

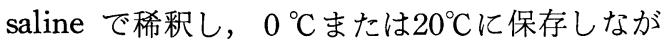
ら経時的に PRP に加えて終濃度を $3 \mathrm{nM}$ とし， 


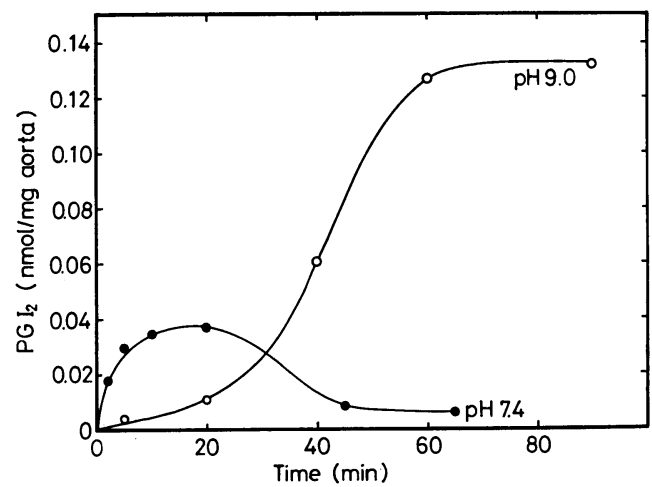

Fig. 1 Prostacyclin activity as a function of time. Rings of the aorta were suspended either in $\mathrm{pH}$ 7.4 Tris-bufered saline $(1 \mathrm{ml})$ or in $\mathrm{pH} 9.0$ boratebuffered saline $(1 \mathrm{ml})$ and incubated at $20^{\circ} \mathrm{C}$. Aliquots $(1-10 \mu \mathrm{l})$ of the supernatant were separated at varying periods of time and their prostacyclin contents were estimated as soon as possible.

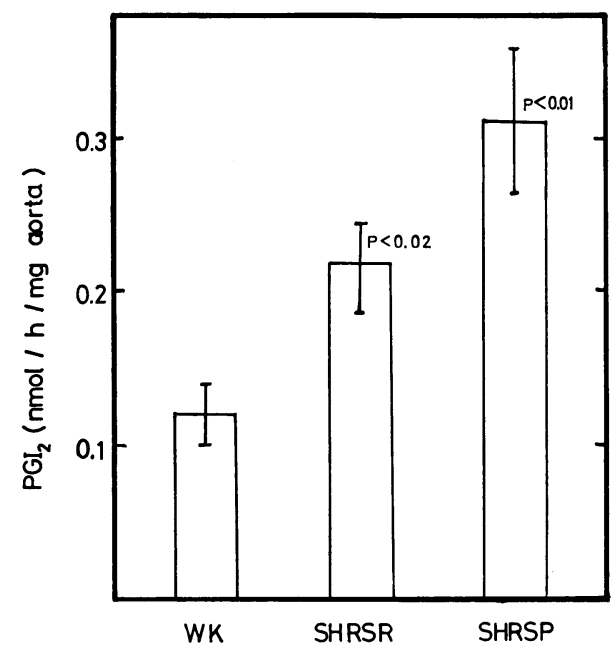

Fig. 3 Prostacyclin production by the aorta of SHRSP and of SHRSR as compared with that of normotensive WK rats. Each bar denotes mean $\pm 1 \mathrm{~S}$. E. Statistical significance was assessed by the t-test as compared with WK rats.

ADP $(5 \mu \mathrm{M})$ 凝集におよぼす阻害効果 の減弱 により $\mathrm{PGI}_{2}$ の安定性を検討した. その結果 $20^{\circ} \mathrm{C}$ では $\mathrm{pH} 9.0$ で約 1 時間, $\mathrm{pH} 10.1$ では 約 6 時間， $0{ }^{\circ} \mathrm{C}$ では $\mathrm{pH} 9.0$ で約 7 時間， $\mathrm{pH}$ 10.1 なら 28 時間後であ それぞれ安定であるが

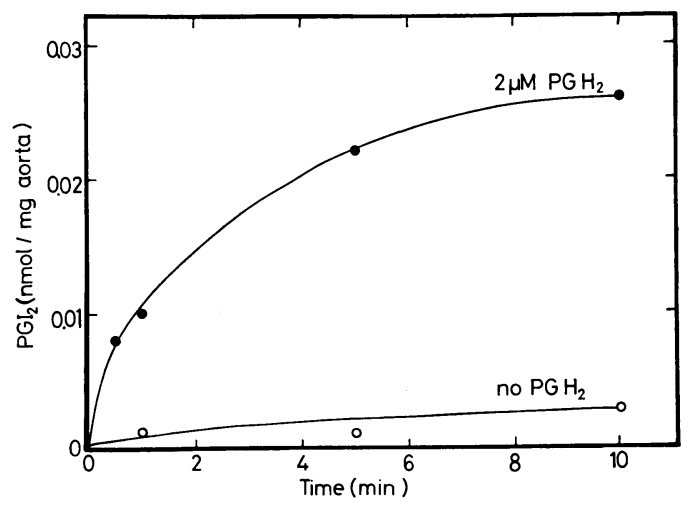

Fig. 2 Prostacyclin production from $\mathrm{PGH}_{2}$ by the indomethacin-treated aorta. Rings of the aorta were incubated with 0.1 $\mathrm{mM}$ indomethacin for $15 \mathrm{~min}$ at $20^{\circ} \mathrm{C}$, washed twice in cold saline and suspended in $\mathrm{pH} 9.0$ borate-buffered saline. These indomethacin-treated aorta were immediately incubated either $2 \mu \mathrm{M}$ $\mathrm{PGH}_{2}$ or with its vehecle (control) at $20^{\circ} \mathrm{C}$. Aliquots of the supernatant were taken out at varying periods of time and their prostacyclin contents were estimated without delay.

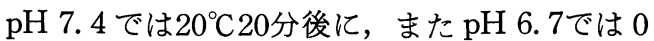
${ }^{\circ} \mathrm{C}$ で 15分後にはそれぞれほとんど活性のない ことがわかった。

\section{2. 大動脈による $\mathbf{P G I}_{2}$ 産生}

種々の $\mathrm{pH}$ の buffered saline に血管を加え て $20^{\circ} \mathrm{C}$ に incubate すると $\mathrm{ADP}, \mathrm{AA}$ または collagen による血小板凝集を抑制する物質が産 生された. $\mathrm{pH}$ 8.0以下の buffered saline 中で はこの物質は $0{ }^{\circ} \mathrm{C}$ 保存でも速やかに失活し， $\mathrm{pH} 9.0$ 以上では $0{ }^{\circ} \mathrm{C}$ で比較的安定であった。 さらに熱処理 $\left(100^{\circ} \mathrm{C} ， 3\right.$ 分) された大動脈で はその活性が生じないととからす大動脈片の incubation で生じたこの物質は $\mathrm{PGI}_{2}$ 之考えら れた.

\section{3. 血管の長さ（重量）と $\mathbf{P G I}_{2}$ 産生量}

$1 \mathrm{ml}$ の $\mathrm{pH} 9.0$ borate-buffered saline $に$, 同一ラットから連続的に切断した種々の長さ (0.5 $3 \mathrm{~m} \mathrm{~m})$ の大動脈片を加えて $20^{\circ} \mathrm{C}$ で 1 時 間 incubate した際に産生される $\mathrm{PGI}_{2}$ 量は血 管の長さにほぼ比例した。 また incubation 終 了後に血管を濾紙で拭いたのち， dessicator 中 にて室温で一夜乾燥させてから秤量した重量と 
$\mathrm{PGI}_{2}$ 産生量の間にも比例関係が認められたの で，血管による $\mathrm{PGI}_{2}$ 産生はその単位重量 $(\mathrm{mg})$ 当りの数值で表現した.

\section{4. pH 7.4 および pH 9.0 における PGI $_{2}$ 産} 生の時間的経過

異なる $\mathrm{pH} て ゙$ incubate された血管により産 生される $\mathrm{PGI}_{2}$ の活性を検討すると図 1 のごと く, $\mathrm{pH} 7.4$ では10 20分の incubation で最大 となり約 1 時間後にはほとんど消失したが， $\mathrm{pH}$ 9.0では約 1 時間の incubation で最大とな った. $\mathrm{pH} 7.4$ では $\mathrm{PGI}_{2}$ は容易に分解される ためと考えられるので以下の実験は $\mathrm{pH} 9.0$ で 1 時間 incubate した際の $\mathrm{PGI}_{2}$ を測定した。

5. Indomethacin (IM) 処理血管による $\mathbf{P G I}_{2}$ 産生

$0.1 \mathrm{mM} \mathrm{IM}$ と $20^{\circ} \mathrm{C} ， 15$ 分間予め incubate し た血管を冷生食水で 2 回洗涤後 $\mathrm{pH} 9.0$ の buffered saline に浮遊させ, $\mathrm{PGH}_{2}(2 \mu \mathrm{M}$, f.c. $)$ またはその溶媒(acetone)のみを加えて incubate すると図 2 のごとく $\mathrm{PGH}_{2}$ を加えた場合は速や かな産生が認められたが対照では10分後までは その産生が認められなかった。これはIM によ り大動脈の cyclo-oxygenase が阻害されたため endogenous には PG endoperoxides が生成さ れず， exogenous に $\mathrm{PGH}_{2}$ を加えると血管の $\mathrm{PGI}_{2}$ 合成酵素により $\mathrm{PGI}_{2}$ が生成されたと考 えられる，乙の実験により血管には $\mathrm{AA} \rightarrow \mathrm{PG}$ endoperoxides $\rightarrow \mathrm{PGI}_{2}$ の代謝系の存在するとと がわかった。

6. SHR と正常血圧ラットにおける $\mathbf{P G I}_{2}$ 産生の比較

SHRSP, SHRSR およびWK 系ラットにつ いて得られた成績を図 3 亿示した. $\mathrm{PGI}_{2}$ 産生 量の平均は $\mathrm{SHRSP}>\mathrm{SHRSR}>\mathrm{WK}$ ラットの 順であり SHRSP と SHRSR 間に有意差は認 められなかったか，乙れらの SHR 群と WK ラット群間にはそれぞれ有意な差が認められ た. SHR におけるこのような $\mathrm{PGI}_{2}$ 産生立進 の機序や意義は目下明らかでないが，高血圧な ごの血管障害性因子に対する防御反応とも推察 される. $\mathrm{PGI}_{2}$ 産生は正常な状態で血管壁への
血小板の蓄積を防止する機序と考えられてお $り^{1)}$ ， とくに SHRSP においては何らかの機序 により血管でのその産生が抑制されると脳卒中 を発症させる引金になるととも考えられるので その点を検討中である.

\section{結論}

$\mathrm{PGI}_{2}$ の血小板凝集抑制効果を指標として, ラット動脈による $\mathrm{PGI}_{2}$ 産生を定量的に検討 し，正常に比し高血圧ラット (SHR) において はその産生が有意に㠵進していることを明らか にした。

\section{文献}

1) Moncada S., Gryglewski, R., Bunting, S. and Vane, J. R.: An enzyme isolated from arteries transforms prostaglandin endoperoxides to an unstable substance that inhibits platelet aggregation. Nature, 263; 663 665, 1976.

2) Moncada, S., Higgs, E.A. and Vane, J.R.: Human arterial and venous tissues generate prostacyclin (prostaglandin $\mathrm{X}$ ), a potent inhibitor of platelet aggregation. Lancet, $1 ; 18 \sim 20,1977$.

3) Villa, S., Mysliwiec, M. and de Gaetano, G.: Prostacyclin and atherosclerosis in rats. Lancet, 1; 1216 1217, 1977.

4) Okamoto, K., Yamori, Y. and Nagaoka, A.: Establishment of the stroke-prone spontaneously hypertensive rats (SHR). Circul. Res., 34 and 35 (Suppl. 1); 143 $\sim 153,1974$.

5) Yoshimoto, T., Yamamoto, S., Okuma, M. and Hayaishi, O.: Solubilization and resolution of thromboxane synthesizing system from microsomes of bovine blood platelets. J. Biol. Chem., 252; 5871 5874, 1977.

6) Johnson, R. A., Morton, D. R., Kinner, J. H., Gorman, R. R., McGuire, J. C. and Sun, F.F.: The chemical structure of prostaglandin X (prostacyclin). Prostaglandins, $12 ; 915 \sim 928,1976$. 